\section{Network Centrality and Performance: Effects in the Automotive Industry}

\author{
Augusto Squarsado Ferreira ${ }^{1}$ \\ Mário Sacomano Neto ${ }^{2}$ (i) \\ Silvio Eduardo Alvarez Candido ${ }^{3}$ \\ Gustavo Mendonça Ferratti ${ }^{4}$
}

\begin{abstract}
Purpose - This paper seeks to assess and analyze the relationship between indegree centrality and organizational performance in the automotive industry. In other words, we look at whether the network position is related to the performance of the actors using production, revenue, and profit indicators.
\end{abstract}

Theoretical framework - This research uses social network analysis as a method/ theoretical approach allied with relational capital.

Design/methodology/approach - A similarity assessment was carried out. Data were collected from 1359 relations across four specific governance structures between 2011 and 2013. Later, the same measures were implemented in subgroups detected with the Louvain method. The NodeXL, UCINET, and SPSS software were used for the graphs, metrics, and correlations, respectively.

Findings - The results show a moderate to strong correlation between the actors and the subgroups formed by them, with their respective revenue and the indegree centrality for the three years selected. Our conclusions were that the centrality of an automotive manufacturer is positively related to its performance.

Practical \& social implications of research - This study might help organizations evaluate social network analysis usage as a tool for understanding their opportunities given their network.

Originality/value - This paper contributes to the literature by indicating that in the automotive industry, formed by alliances between different governance structures, the structural position a manufacturer occupies in the network is related to its performance indicators.

Keywords - automotive industry; interorganizational network; social network analysis; performance measures; similarity analyses.

1. Concordia University, Department of Mathematics and Statistics, Montreal, Canada

2. Federal University of São Carlos, Department of Production Engineering, São Carlos, Brazil

3. Federal University of São Carlos, Department of Production Engineering, São Carlos, Brazil

4. Federal University of São Carlos, Department of Production Engineering, São Carlos, Brazil

\section{How to cite:}

Ferreira, A.S., Sacomano Neto, M., Candido, S.E.A., Ferratti, G.M. (2021). Network Centrality and Performance: Effects in the Automotive Industry. Revista Brasileira de Gestão de Negócios, 23(4), p.677-695.
Received: 06/09/2020

Approved: 04/15/2021

Responsible Editor:

Prof. Dr. Eduardo Armando

\section{Evaluation process:}

Double Blind Review

\section{Reviewers:}

Charles Kirschbaum; One of the reviewers decided not to disclose his/ her identify.

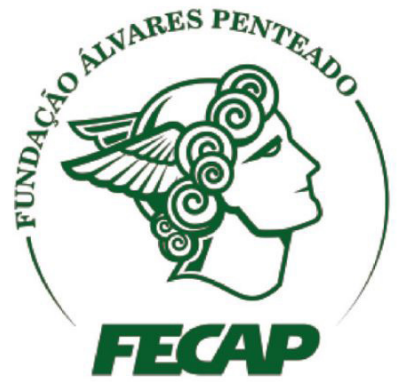

Revista Brasileira de Gestão de Negócios

https://doi.org/10.7819/rbgn.v23i4.4132 


\section{Introduction}

Network analysis can be a mighty resource for understanding the economy and society (Borgatti, Mehra, Brass, \& Labianca, 2009; Jackson, 2010; Kilduff $\&$ Brass, 2010). Network phenomena can be related to a new form of governance and a method to understand the socioeconomic world (Borgatti et al., 2009; Owen Smith \& Powell, 2008). As a form of governance, networks encompass several forms of partnerships, such as alliances, consortiums, joint ventures, and other multiple modes of cooperation in research and development, production, and marketing (Owen Smith \& Powell, 2008; Lewis, 2011; Provan $\&$ Kenis, 2008). These initiatives are usually strategical, providing mutual benefits through cooperation (Bamford \& Forrester, 2003; Das \& Teng 2003; Gulati, Wohlgezogen, \& Zhelyazkov, 2012).

As a new form of governance, network analysis encompasses new challenges to understand the structural and relational aspects of social life (Owen Smith \& Powell, 2008), especially because economic transactions are socially embedded and cannot be explained strictly in economic terms (Sacomano \& Paulillo, 2012; Smelser \& Swedberg, 2010; Swedberg \& Granovetter, 1992). Economic sociology suggests that the dynamics of the economy are embedded in social relations (Granovetter, 2018; Owen Smith \& Powell, 2008), which encourages the use of social network analysis (SNA) to address relational and structural configurations of economic arrangements (Borgatti, Brass, \& Halgin, 2014). Network analysis suggests contemplating the social context as the core of any economic phenomenon, and not as a mere externality (Convert \& Heilbron, 2007). In this approach, organizations have to be contextualized in the structural and relational positions they occupy in complex business relationships (Borgatti et al., 2014; Owen Smith \& Powell, 2008; Sacomano, Matui, Candido, \& Amaral, 2016).

Within this literature, just a few studies provide ways to relate specific performance measures with the positions of organizations in the structure of networks (Gulati \& Gargiulo, 1999; Provan, Fish, \& Sydow, 2007; Wang, Zhao, Li, \& Li, 2015; Zaheer, Gözübüyük, \& Milanov, 2010). Provan et al. (2007) highlight different studies concerning performance metrics at the "whole network” level. Similarly, Zaheer et al. (2007) propose a framework which can be used to organize network performance relationships, and Wang et al. (2015) address the relationship between innovation and network centrality metrics.

This topic may also be related to the emergent forms of governance in the automobile industry: crossshareholding, joint ventures, manufacturing contracts, and alliances (Freyssenet, 2009; Sacomano et al., 2016; Wang et al., 2016). These forms of governance have grown substantially in the automotive industry, involving different structures (Freyssenet, 2009; Matui \& Sacomano, 2017; Wang et al., 2016). They may be observed in partnerships such as Renault-Nissan (https://www.economist.com/ business/2010/06/10/all-together-now, retrieved in 2020, June 29 $9^{\text {th }}$ ), Ford-Mazda (Freyssenet, 2009), General Motors-PSA, Volkswagen-Suzuki, Renault-NissanDaimler AG (Wang et al., 2016), Fiat-Chrysler (Ichijo \& Kohlbacher, 2008; Lee \& Jo, 2007), Nissan-Mitsubishi (https://www.economist.com/business/2016/05/12/ nissan-and-mitsubishi-make-an-alliance, retrieved in 2020, June 29th), and Fiat-Peugeot (https://www.reuters.com/ article/us-fca-m-a-psa/fiat-chrysler-peugeot-maker-psaamend-merger-terms-to-conserve-cash-idUSKBN2653AE, retrieved in 2020, June 29th). Understanding them is essential in the current context of economic integration, high competition, and complexity in terms of production standards and productive scale (Gomes-Casseres, 1994; Wit \& Meyer, 2010).

Although some studies explore specific performance measures and network structural positions (Gulati \& Gargiulo, 1999; Provan et al., 2007; Wang et al., 2015; Zaheer et al., 2010), no research was found to relate specific performance measures and network structural positions in the automobile industry. Furthermore, previous studies have not embraced the following aspects at the same time: (i) the plurality of relationships found in the automotive industry (Soda, 2011; Tatarynowicz, Sytch, \& Gulati, 2016) and (ii) the relationship between actors' centrality metrics and organizational attributes such as revenue, production, and performance (Powell et al., 1999; Shipilov, 2009).

In this article, we assess the relationship between network positioning through indegree centrality and organizational performance in the automotive industry, using production level, revenue, and profit indicators. Our sample includes a major portion of the organizations in the automobile industry, including around $85 \%$ of world vehicle production (https://www.oica.net/category/ production-statistics/, retrieved in 2020, June 29th). We explore whether a positive relationship is observable 
between multiple performance indicators and centrality metrics in network positioning. Different types of governance structures and performance indicators were considered at the same time, as well as two levels of analysis regarding the centrality metrics: one focused on the organization's performance by itself (organization's indegree centrality) and the other focused on the organizational performance of prominent automotive groups (subgroup's indegree centrality). Therefore, as specific objectives, we evaluate the indegree centrality for each actor in the network and identify the communities and groups, followed by an evaluation of indegree centrality as well, to finally explore the similarity between indegree centrality and performance.

We incorporate indegree centrality because we wanted to examine how the inflow of money was similar to the indegree centrality for each actor and subgroup; and we encompass performance indicators since these are the most practical and straightforward measures to deal with. Centrality is a useful network property, with rich inferences about actors' structural and relational positions (Borgatti, Everett, \& Freeman, 2002). An actor's centrality, for example, implies prominent positions in the network to access innovation, information, markets, and other competitive and institutional resources.

Our results show that there is a positive relationship between indegree centrality and the automakers' organizational revenue. The Louvain algorithm (Aynaud, Blondel, Guillaume, \& Lambiotte, 2013; Gach \& Hao, 2013) detected a strong community structure for the network, where groups also displayed greater performance attributes associated with higher indegree centrality.

The paper has the following structure. First, we carry out a literature review, exploring networks and governance, as well as the concepts of centrality and performance. Second, we explain our method in two stages, data collection and data analysis, emphasizing our sources, the procedures followed, and the metrics used. Third, we present our results through graphs and descriptive statistics and discuss our findings.

\section{Literature Review}

\section{I Networks: governance and analysis}

There are two approaches to the study of networks in economics: networks as a form of governance and networks as a method of analysis (Smith-Doerr \& Powell, 2005). While in economic theory the rational choice approach emphasizes atomistic decision-making processes (Schulz, 2016), the network approach assumes that economic transactions are embedded in social relations (Granovetter, 1973; Granovetter, 2017). Networks objectively represent social structures that both enable and constrain economic action (Brailly, Favre, Chatellet, \& Lazega, 2016; Granovetter, 1973; Smith-Doerr \& Powell, 2005). They facilitate access to multiple forms of material (economic capital, economies of scale) and immaterial (information, knowledge, prestige) resources for firms, enabling their actions and economic performance (Gulati, 2007; Powell et al., 1999; Uzzi, 1997; Westphal, Gulati, \& Shortell, 1997). They also define limits to organizations and function as conduits that can propagate social instabilities and uncertainty.

Networks entail positive or negative interactions, involving relationships of cooperation or conflict. In the case of firm alliances, the structure of interactions is positive and tends to operate as a form of resource, enabling social connections and the gains related to them (Granovetter, 2017). For some authors, the network structure of industries is considered a constellation of alliances (Garcia-Pont \& Nohria, 2002; Nohria \& Garcia-Pont, 1991). Scholars have studied how firms' alliances in a particular industry may explain their heterogeneous performance (Bamford, Gomes-Casseres, \& Robinson, 2003; Koka \& Prescott, 2008). In these assessments, the authors assume that companies are not homogeneous, but instead have varied scales, types of products and services regarding price, features, and quality, and types of customers served, etc. (Das \& Teng, 2003; Goerzen, 2007). As a result, the network structure of industries encompasses the exchange of information, resources, and influence (Gulati, 2007; Powell et al., 1999).

Companies with a similar strategic focus compete directly with one another and have been called strategic groups (Nohria \& Garcia-Pont, 1991). These companies tend to occupy structurally equivalent positions in complex industrial networks, reflecting the intersubjective representations of the managers about who their main competitors are (Porac, Thomas, Wilson, Paton, \& Kanfer, 1995). They have common ties with companies from other strategic groups, establishing partnerships with them and strategic blocks that depend on relationships of trust (Nohria \& Garcia-Pont, 1991; Ratajczak-Mrozek, 2017; Sacomano et al., 2013). These alliances establish specific combinations of network resources, combinations that are not easily replicable by other competing blocks (Gulati, 
2007). The groups' differential network resources may be deployed strategically to generate economic results, which may explain inter-block differences in performance. In the next section, we review the literature that addresses the relationships between specific performance measures and network structural positions.

\subsection{Network centrality and performance}

In networks of positive interactions, centrality implies an important competitive advantage (Freeman, 1979; Granovetter, 2017). It entails not only the direct linkages among firms but also the indirect ones. So, the connection of a firm with other well-connected ones enhances its centrality. A firm's centrality in an alliance network may be associated with certain resource endowments, which are used in its competitive strategies and may lead to the further accumulation of resources.

Centrality in an alliance network is considered to be positively associated with firm performance because of two major factors. First, the establishment of ties is an indicator of the popularity or the reputation of a certain actor in the network (Nooy, 2003; Prell, 2012). As an actor's reputation is related to the possession of other competitive resources, especially the ones shareable in an alliance relationship, centrality works as an indicator of firms' overall resource endowments (Burt, 2009; Macaulay, Richard, Peng, \& Hasenhuttl, 2018).

Second, centrality is directly connected to the possession of relational resources, facilitating access to other material and immaterial resources, and it may be used to leverage internal sources of competitive advantage (Kim \& Tsai, 2012). Firms with other capabilities tend to benefit more from resources that flow through social ties with other firms than those with low overall dominance over resources. However, for this to happen, firms need to have the ability to gain from external connections by avoiding getting too close to their own strong competitors and they have to prevent the protection of their privileged competencies impeding fruitful exchanges with partners (Srivastava \& Gnyawali, 2011). The accumulation of alliance ties by a particular firm enables entry into new successful alliances, as it facilitates access to information to support strategic decisions (Gulati, 1999).

One level of analysis in SNA is subgroups (Marin \& Wellman, 2011). According to Hansen, Shneiderman, and Smith (2010) and Scott (2017), subgraphs of a graph can be understood as a complex combination, of a random nature or not, of points in a whole network, forming smaller groups known as clusters or communities. Barabási (2002) and Scott (2017) emphasize that in studies of the structural properties of social networks, subgraphs and networks themselves are not random in their conception, since the formation of social structures and groups, as well as chemical and biological networks, for example, have more straightforward explanations.

The modularity concept presented by Newman (2006, 2010) divides the subdivision of a network into subgroups or communities as an attempt to identify substructures. The author defines substructures as subgroups that have more links within the group than between groups, considering each node's degree of centrality and the size of the group (Hanneman \& Riddle, 2011).

Analogous to the calculation for nodes and links that affect them, the actors' centrality has been extended to metrics that transpose them into subgroups in a graph, as observed by Bell (2014) and Everett and Borgatti (1999). This relationship between centrality and the cohesive structure of subgroups was analyzed in the literature by Bodin and Crona (2009) and by Moody and White (2003) between node connectivity and related social cohesion and immersion.

Exploring a gap not covered by the previous authors (Gulati \& Gargiulo, 1999; Provan et al., 2007; Zaheer et al., 2010), in this article we try to explore whether a positive relationship is observable between multiple performance indicators and centrality metrics in network positioning, considering different types of governance structures and performance indicators at the same time. Our hypotheses are: (H1) actors with greater indegree centrality in a network tend to have greater attributes of production, revenue, or profit; $(\mathrm{H} 2)$ the subgroups identified in the network with greater indegree centrality tend to have greater attributes of production, revenue, or profit.

\section{Method}

A quantitative study was developed to accomplish the established objectives, combining social network analysis and correlation analyses. The study focused on 19 automakers, which accounted for approximately $85 \%$ of the world's vehicle production, according to https:// www.oica.net/category/production-statistics/ (retrieved in 2020, June 29th). The period analyzed is from 2011 to 2013 and four different types of alliances are observed, as detailed below. 


\section{I Data collection}

A longitudinal data collection (Wasserman \& Faust, 1994) was performed, observing alliances of worldwide automotive manufacturers regarding crossshareholding, joint ventures, manufacturing contracts, and technical and parts alliances. The database covering 2011 to 2013 is an annual global summary called Guide to Global Automotive Partnerships from Automotive News (2011-2013). Regarding the actors' revenue and profit data, these were collected using the companies' annual reports on operating highlights or income statement data such as "Revenues" and "Net Income" values, available on their respective websites or the internet (see References). Because we wanted to work with American dollars (USD), we had to set the exchange rate for all the non-dollar listed amounts on the year-end closing date available in the reports. As for production, the numbers were taken from the International Organization of Motor Vehicle Manufacturers website (https://www.oica.net/category/ production-statistics/, retrieved in 2020, June 29th) on a yearly basis.

To deal with data missing from the guide or to confirm if an observed joint-venture was not a contract assembly or a technology and parts alliance (https:// www.just-auto.com/news/proace-is-first-psa-built-toyotavan_id127942.aspx, retrieved in 2020, June 29th), we used Bloomberg (https://www.bloomberg.com/), Automotive News (https://www.autonews.com/), and Just-Auto (https:// www.just-auto.com/) along with Google searches for each partnership presented in the guide, entering strings that contained the manufacturers' names, the presumed alliance, plus the name of each website to find out more about the partnership. After careful consideration, we compared the information in the guide with the information on the website, adding alliances to the database according to the source information. To standardize the dates when alliances were established with respect to the year, we preferred to only add them when they had effectively started by the last day of that specific year.

The 1359 arcs collected were divided into four major categories and distinct governance structures and were later treated as directional and valued, employed in non-binary and non-symmetric matrices. These ties were categorized and henceforth treated as ESO (equity stake ownership), T\&PA (technical and parts alliance), CA (contract assembly), and JV (joint venture). According to Table 1, the "Actor A" column corresponds to the origin, and the "Actor B" column to the target of the tie, as a result of prior interpretation of the money flow for each alliance set in one specific row. The interpretation given to every tie with respect to its own characteristics was essential to understand the data arrangement in Table 1.

The direction of the alliance conveys the following interpretation with respect to its type: ESO - "Actor A is owned by Actor B" corresponds to the ownership of Actor B over Actor A; T\&PA - "Actor A acquired technology or parts from Actor B" represents an alliance between two actors that aim at the joint development/ purchase of technologies or parts for vehicles expressed as a bidirectional arc, or Actor's B technology acquisition from Actor A.

Contract assembly - "Actor A had its vehicles produced in factories of Actor B" represents alliances between two actors for shared vehicle manufacture operation; and JV - "Actor A is a joint venture owned by Actor B" is used for the association of two actors to create a new company that serves specific strategic purposes.

\subsection{Data analysis}

Among the multiple centrality metrics that exist, we chose degree centrality to give a more direct and immediate notion of the number of business partnerships established in each automotive organization or organizational group. Other options would be: (1) closeness centrality, to measure

\section{Table 1}

\section{Arrangement of collected data}

\begin{tabular}{ccc}
\hline Actor A - Origin & Actor B - Target & Type \\
\hline NISSAN MOTOR CORP. & RENAULT SA & ESO - cross-shareholding \\
FIAT S.P.A. & CHRYSLER GROUP & T\&PA - technology/parts alliance \\
BMW AG & Magna Steyr LLC & CA - manufacturing contracts \\
NMKV Ltd. & MITSUBISHI MOTORS CORP. & JV - joint venture \\
NMKV Ltd. & NISSAN MOTOR CORP. & JV - joint venture \\
\hline
\end{tabular}


the ease of information diffusion through the shortest paths between actors; or (2) betweenness centrality, to observe how much a given actor acts as a "bridge" in the shortest path (Wasserman \& Faust, 1994).

Degree centrality was chosen because we are dealing with partnership contracts in an explanatory and non-predictive model. We focused on looking at each actor's influence in terms of agreements that have already been established between actors and not in terms of their role as a connector for closing new partnerships. Thus, degree centrality seems to make the most sense for the objectives of the work.

Regarding the directionality of the links, we opted for indegree metrics over outdegree ones because we are interested in knowing the number of commercial partnerships that the node in question had as a "target" or object of interest of the formal contracts, and are not interested in determining the number of contracts that the evaluated node made with other companies.

The network was visualized through sociograms created via NodeXL (https://www.smrfoundation.org, retrieved in 2020, June 29th), and the data analysis was performed in UCINET 6 (Borgatti et al., 2002). These multiplex networks allow the creation of yearly sociograms, with the graphic visualization of actors, subgroups, and relations in the same graph.

Before beginning the analyses, the matrices containing each relationship were aggregated and added to a non-symmetric valued matrix for each year, whose cells can take values ranging from 0 to 4 , where 0 is the absence of an alliance between two actors and 4 is the existence of 4 alliances between them. These weighted relationships are beneficial since they do not generate information loss when analyzed by the algorithms.

Regarding the identification of groups, the Louvain algorithm was chosen due to its capacity to easily handle non-binary and targeted matrices based on the modularity criteria (Orman, Labatut, \& Cherifi, 2012), which is our case. The algorithm is divided into two phases, called the Vertex Mover Procedure and Coarsening Phase, repeated alternately until maximum modularity is achieved (Aynaud et al., 2013; Gach \& Hao, 2013). According to the authors, the first phase consists of finding a relative local optimum, where each vertex can only be connected to one community in its direct neighborhood. The second phase aggregates the vertices in metagraphs, so that the first phase graph leads to a collection of vertex movements at a more global level. As a result of the algorithm, we have a solid group identification based on maximum modularity.

The correlation analyses and statistical significance tests were performed in the Software Package for the Social Sciences (SPSS) version 23. Three statistical procedures were applied: the Pearson's product-moment correlation coefficient, the Spearman's rank correlation coefficient, and the Monte Carlo permutation test. We chose these tests because the Pearson's and Spearman's correlation coefficients deal with interval or ratio variables (Hauke \& Kossowksi, 2011; Somekh \& Lewin, 2005), and the Monte Carlo permutation test is able to handle data where the widespread asymptotic methods cannot address the inherent characteristics of relational data, such as the unknown probabilistic distribution and non-random samples varying in size and representativeness of the whole population, as well as the actors' interdependency (Borgatti, Everett, \& Johnson, 2013; Hanneman \& Riddle, 2005; Prell, 2012; Scott, 2017).

Moreover, as Mehta and Patel (2011) stated, the Monte Carlo test must be chosen when the exact method is time-consuming and computationally insufficient due to large data sets, since it always produces reliable results, regardless of the data size, distribution, sparseness, or balance. The test is also quite similar to the exact method, except that instead of looking for all the possible data arrangements, the researcher previously stipulates how many resamples the Monte Carlo test will execute (Berry, Johnston, \& Mielke, 2014).

\section{Results}

This section explores the structure and relationships in the network, describing the communities and groups, to explore the similarity of indegree centrality and performance.

\section{I Governance: structure and relationships}

Based on the assumption that the network analyzed observes the money and resource flow of each relationship, the indegree metrics shown in Table 2 are indicators of the actors' money inflow, determined by the number of observed relationships, whereas Figure 1 contains their composition regarding governance.

Figure 1 shows that more central actors had a greater multiplexity of ties. These actors include Daimler, GM, Fiat, Renault, Nissan, and Toyota, whose 
Table 2

\section{Automotive manufacturers' indegree cen- trality values}

\begin{tabular}{|c|c|c|c|}
\hline & 2011 & 2012 & 2013 \\
\hline & Indegree & Indegree & Indegree \\
\hline BMW & 13 & 12 & 10 \\
\hline Chrysler & 7 & 7 & 7 \\
\hline Daimler & 31 & 31 & 32 \\
\hline FAW & 7 & 7 & 7 \\
\hline Fiat & 24 & 21 & 20 \\
\hline Ford & 18 & 17 & 20 \\
\hline GM & 24 & 25 & 23 \\
\hline Honda & 10 & 9 & 10 \\
\hline Hyundai & 7 & 7 & 6 \\
\hline Mazda & 10 & 10 & 10 \\
\hline Mitsubishi & 10 & 10 & 11 \\
\hline Nissan & 17 & 15 & 18 \\
\hline Porsche & 3 & - & - \\
\hline PSA & 18 & 20 & 16 \\
\hline Renault & 24 & 22 & 22 \\
\hline SAIC & 8 & 8 & 8 \\
\hline Subaru & 3 & 3 & 3 \\
\hline Suzuki & 12 & 12 & 12 \\
\hline Toyota & 17 & 17 & 17 \\
\hline Volkswagen & 19 & 17 & 17 \\
\hline
\end{tabular}

portfolios of contracts were diverse and spread out over multilateral combinations. Daimler, GM, Renault, and Fiat have higher indegree values, especially the first one. The greater values mean that these automakers received more money during that period due to profits from their joint venture or payments for services and technologies provided. Daimler has a higher indegree value than the others, as 17 out of 31 relationships are solely equity stakes. In contrast, GM has a more heterogeneous formation in its metric, comprising 10 joint ventures and 8 equity stakes in its total value.

The year 2012 did not show many changes compared to the previous one (Figure 1). Regarding the automakers with a higher metric than the other actors, it is possible to observe that only Fiat suffered a significant change, with three units fewer in the indegree metric. These three relationships correspond primarily to the bankruptcy of the automaker Saab Automobile.

The sale of SEVEL Nord's stake in PSA, the non-renewal of the transmission contract by the French company, and the abandonment of the joint venture between Fiat and Sollers Group were the causes that led to the fall in the metric. On the other hand, the incorporation of
$\mathrm{CNH}$ Industrial by Fiat provided an increase in indegree centrality. The automakers Daimler, GM, and Renault maintained high centrality values.

In 2013, the indegree metric for Daimler was highest with a value of 32 . In addition, GM, Renault, Ford and Fiat had values above 20 units. Daimler increased its indegree metric by 1 , because in 2013 it formed an alliance with Ford, Nissan, and Renault for the joint development of hydrogen fuel cells. Chrysler, FAW, Hyundai, SAIC, and Subaru maintained low indegree values, with Hyundai ending an alliance with Chrysler for the production of the Dodge Attitude in the Indian and Korean factories of the Korean automaker.

Over the years, Daimler obtained an increasingly central position in the network. Daimler's relationships were relatively stable, except in 2013, when an alliance was initiated between Daimler, Ford, Nissan, and Renault for joint hydrogen fuel cell development. Daimler and Ford were already engaged in the Automotive Fuel Cell Cooperation joint venture for fuel cell development but did not have a direct alliance with each other.

In Figures 2 to 4, some characteristics of the network structure and centralities can be visualized. From 2011 to 2012, there was a spatial approach between PSA and GM and a movement to a more central position in the network, mainly of Nissan, Mitsubishi, Suzuki, and FAW. In contrast, Toyota and Subaru ended up in slightly more peripheral positions (see Figures 2 and 3). Regarding the main visual changes observed from 2012 to 2013, Mitsubishi's approach towards Nissan and Renault was observed, as opposed to the separation between Ford and Mazda. Nissan moved to an even more central position, alongside Ford, moving farther away from the periphery and approaching Daimler and the Japanese company as well (see Figures 3 and 4).

On the other hand, the results show that Toyota was less centrally positioned in 2012 compared to the previous year, and PSA was established in a less central portion of the network. Honda, Hyundai, and SAIC did not change either their positions from peripheral parts of the networks nor did they get closer in relation to any of the other actors analyzed (see Figures 2 to 4).

\subsection{Community and subgroups}

Figures 2 to 4 show the network with its subgroups identified for the three years, where the shape and shade of the nodes correspond to the actor's group, the node 


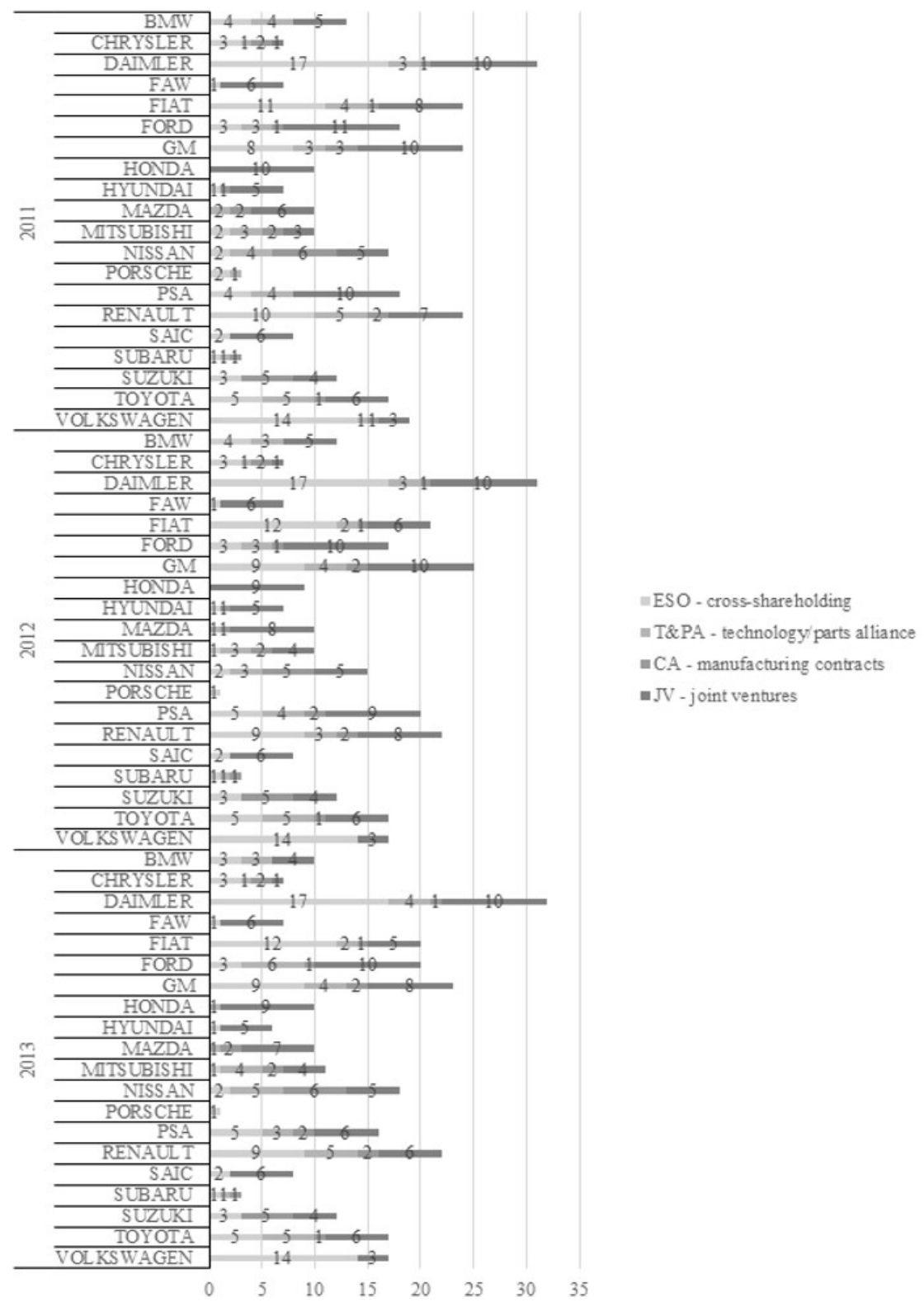

Figure 1 Manufacturers' alliance composition

size corresponds to that actor's indegree centrality in the year, and the thickness of the ties illustrates the weight of the relationship between the pair of actors. In the first year, 12 groups were identified according to the algorithm resulting in a maximized modularity of $Q=0.667$. The indegree metrics of each group are presented in Table 3.

Thus, for 2011, 11 of the 12 groups are exhibited, since one of the subgroups formed contained only Renault Pars, Iran Khodro Co., and SAIPA Group, without the participation of one of the 20 main actors. It is relevant to state here that these subgroups' metrics are calculated using all the actors belonging to the network within each subgroup and not only the separate actors.
As seen in Table 3, some companies known as partners in the automotive industry were relocated to the same subgroup in the network, such as the Ford and Mazda groups, Nissan and Renault, and Chrysler and Fiat. The automakers Mitsubishi, PSA, Honda, BMW, and Hyundai were not allocated to any other major players. There are 14, 18, 31, 22, and 21 actors in each group, respectively associated to each isolated assembler in the analysis.

As observed in Figure 3, at first glance the network configuration in 2012 presents some characteristics that are distinct from the 2011 network concerning the subgroups formed. First, the Louvain algorithm found 10 subgroups 


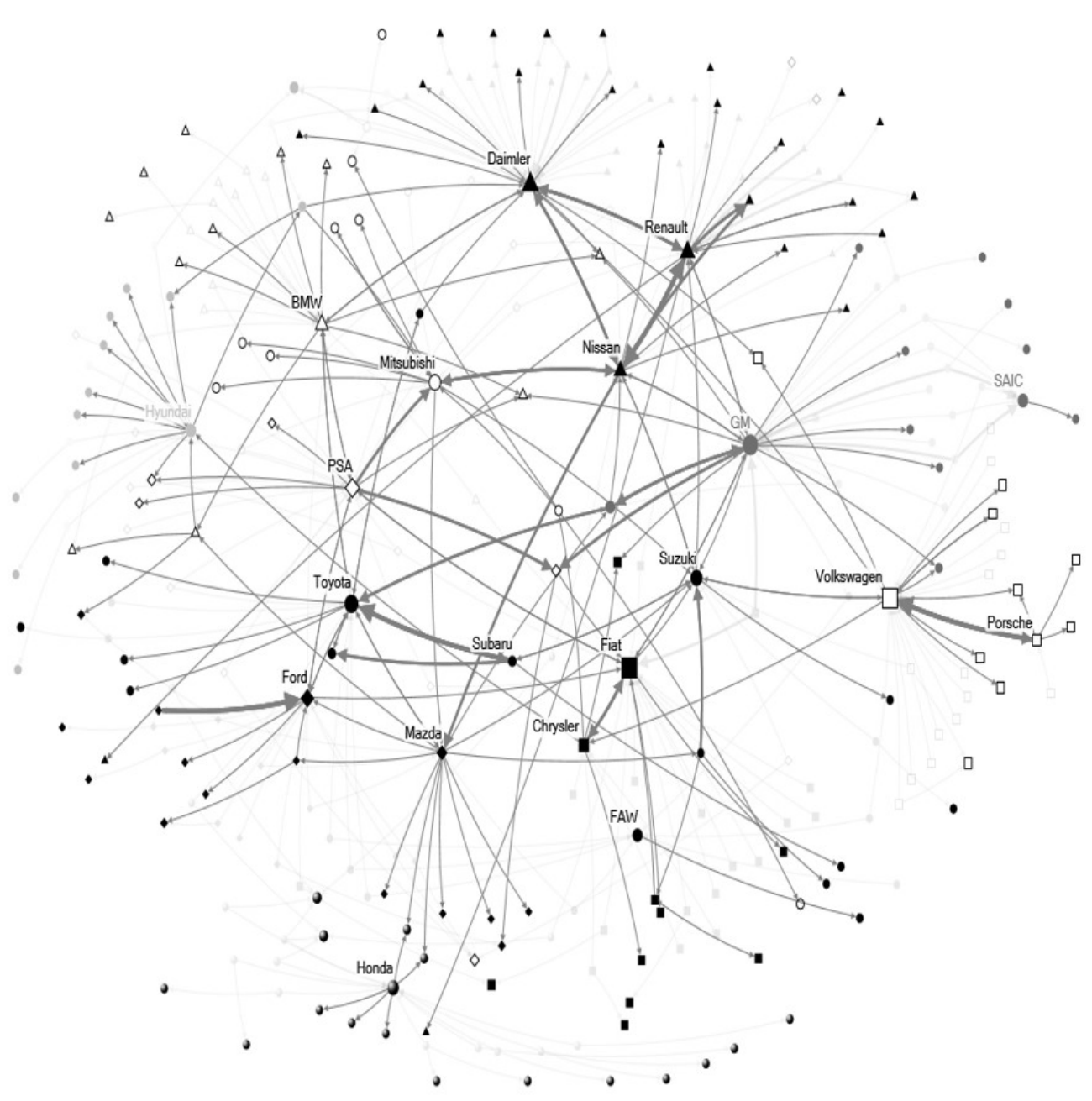

Figure 2 Automotive manufacturers' networks and their subgroups - 2011

in the maximum modularity of $\mathrm{Q}=0.661$, and again a subgroup formed by the same three actors did not contain any of the major assemblers, and so it was removed from both the statistical analyses and from Table 3 .

In this network, the Honda, Hyundai, and BMW assemblers were again allocated to subgroups whose actors out of the 19 taken as a reference by the guide were not selected to share one of the 10 groups identified. Thus, the groups formed by the automakers mentioned above contain 30, 26, and 21 actors, respectively, against 31, 21, and 22 in 2011. The top-rated actor in the Honda group was GAC Mitsubishi Motors, the five biggest actors in the Hyundai group were China Motor Corporation, FJMG Motor, Fujian Benz Automotive, Fujian Motors Group, and Soueast Motor, and the lesser actor in the BMW group was Inokom Co., which was allocated to the Mazda and Ford group.

The year 2012 presented two similar groups to the previous year. Regarding groups that presented different configurations, the first is group 4, which in 2012 presented PSA as a new member. This addition of PSA can be understood as being a result of the alliance initiated by them in 2012, in which the American automaker first acquired 7\% of the shares of the French company and started the development and acquisition of technologies and parts in 2012, and the sharing of platforms later.

The second subgroup identified that presented changes was group 5, now composed of Mitsubishi. This approximation between the automakers, which was maintained in 2013, can be conceived as a close relationship between the Japanese carmaker and the established relationship of Renault-Nissan that culminated in 2016 with the last alliance between the three, when Nissan acquired 34\% of Mitsubishi's shares. It can be observed in 2012 that the alliances of T\&PA and CA among the Japanese automakers were maintained. These alliances included the joint development of electric vehicles, 


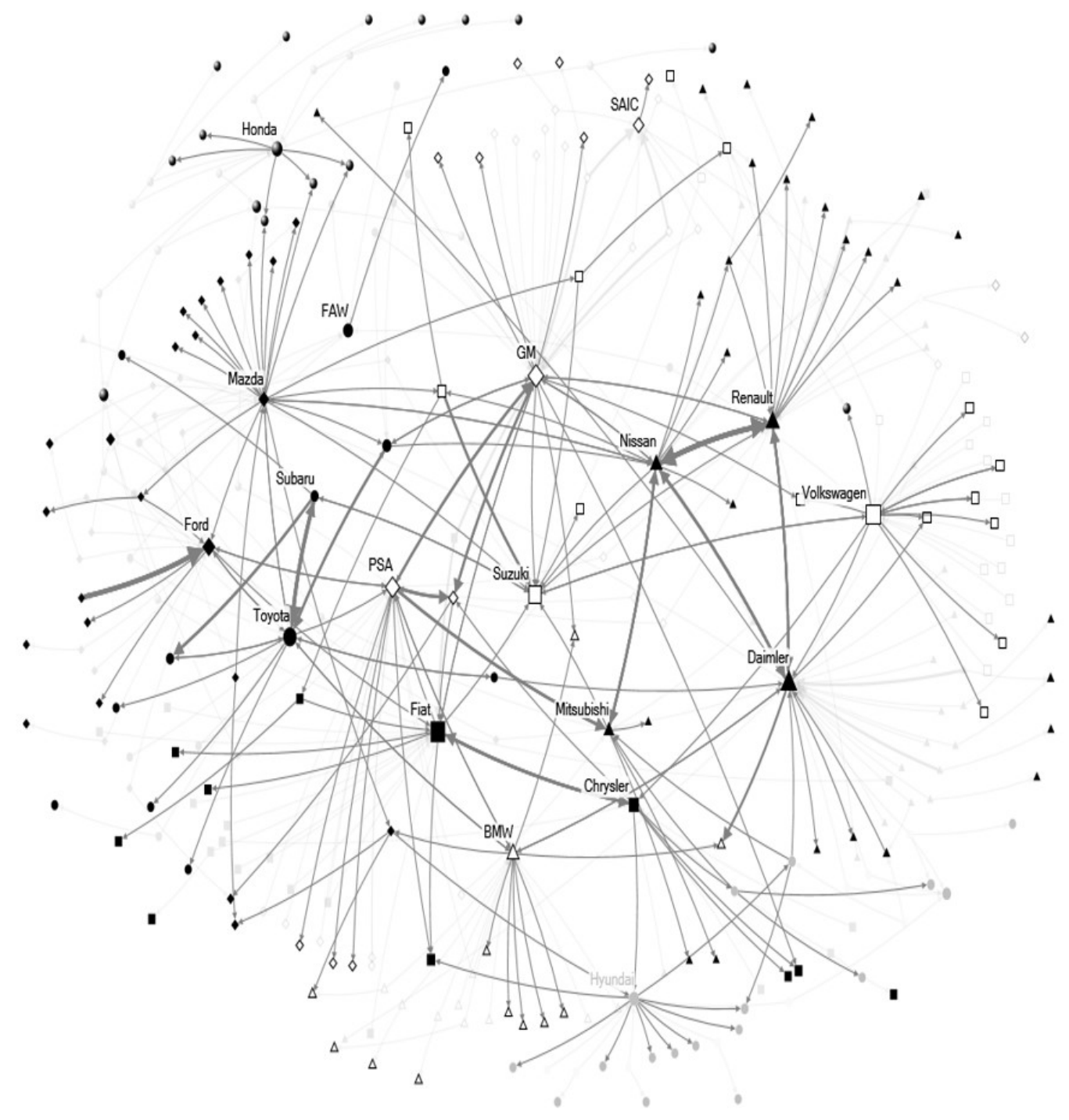

Figure 3 Automotive manufacturers' networks and their subgroups - 2012

such as the MiniCAB MiEV, and platform sharing for the development of the Mitsubishi Proudia, Lancer, and eK, as well as the manufacture of the Nissan Dayz.

The last group analyzed whose composition changed corresponds precisely to Suzuki, which in 2012 belonged to the Volkswagen group, but in 2011 was assigned to the Subaru-Toyota-FAW group. In 2010, Volkswagen acquired approximately $19 \%$ of the Japanese automaker's shares, and Suzuki acquired $1.49 \%$ of the German company's shares. The allocation of three major Japanese automakers in the same group in 2011 was perhaps due to the tsunami, which forced the companies to establish alliances to recover from it.

Regarding 2013, the algorithm identified 10 subgroups with a maximum displayed modularity of $Q=0.660$. In comparison with 2012, there were no changes in the subgroups regarding the main assemblers. The same subgroup identified over the previous two years with three actors was removed, leaving nine groups once again for analysis.

\subsection{Indegree centrality and performance}

The correlations and statistical significance for 2011, 2012, and 2013, displayed in Table 4, show that among the variables analyzed, the one that presented the highest correlation with the indegree metric was revenue. First, the associations between them had a moderate to strong and statistically significant effect for the three years analyzed, particularly in the Spearman correlation between revenue and indegree centrality in 2011, where the p-value was lower than 0.005 . All the other tests of 


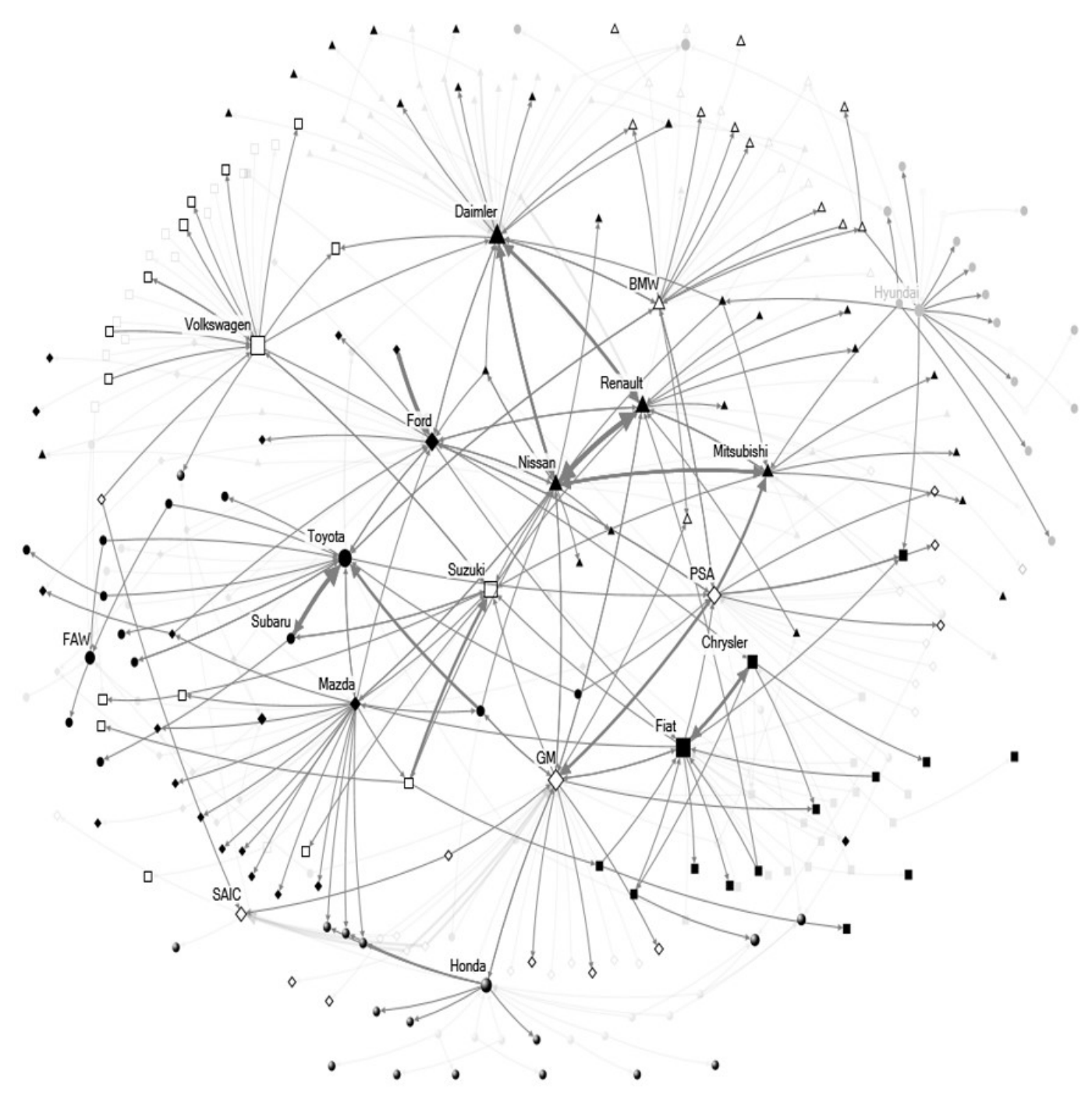

Figure 4 Automotive manufacturers' networks and their subgroups - 2013

significance between the two variables obtained a p-value lower than 0.05 .

According to the first hypothesis that actors with greater indegree centrality tend to have greater attributes of production, revenue, or profit, Table 4 displays a moderate to strong positive association between the money inflow of the main actors in the network and their respective revenues. Nevertheless, particularly in the Spearman correlation for 2011, a robust monotonic relationship between the indegree variable and the production variable can be observed, as well as a moderate monotonic relationship between the centrality metric and corporate profit.

The statistical significance presented between the respective variables mentioned above indicates that the correlations are significantly different from 0 and that there is a respectively linear or monotonic relationship for the Pearson and Spearman correlations among the variables analyzed, thus rejecting the null hypothesis of the absence of a correlation. It should be noted that the lower the p-value, the more robust the finding is that the result of the statistical test was not due to randomness of the data.

The correlations and tests of significance for the actors in the subgroups presented in Table 5 show a strong positive relationship between revenue and indegree centrality, especially in the last two years, which can be observed again in the p-value for the Spearman correlation in 2013, which is below 0.0005 . These results point mainly to a strong similarity between the last two variables of the subgroups formed of the automakers in the automotive industry.

In the specific case of this study, the correlations shown in Table 4 indicate that the automakers' money inflow is positively correlated with their revenue, implying 
Table 3

\section{Subgroups' indegree centrality}

\begin{tabular}{|c|c|c|c|c|c|c|}
\hline & \multicolumn{2}{|c|}{2011} & \multicolumn{2}{|c|}{2012} & \multicolumn{2}{|c|}{2013} \\
\hline & Automakers & Indegree & Automakers & Indegree & Automakers & Indegree \\
\hline Group 1 & Honda & 1 & Honda & 2 & Honda & 4 \\
\hline Group 2 & $\begin{array}{l}\text { Ford } \\
\text { Mazda }\end{array}$ & 8 & $\begin{array}{l}\text { Ford } \\
\text { Mazda }\end{array}$ & 6 & $\begin{array}{l}\text { Ford } \\
\text { Mazda }\end{array}$ & 9 \\
\hline Group 3 & Hyundai & 3 & Hyundai & 2 & Hyundai & 1 \\
\hline Group 4 & $\begin{array}{c}\text { GM } \\
\text { SAIC }\end{array}$ & 9 & $\begin{array}{c}\text { GM } \\
\text { PSA } \\
\text { SAIC }\end{array}$ & 17 & $\begin{array}{c}\text { GM } \\
\text { PSA } \\
\text { SAIC }\end{array}$ & 14 \\
\hline Group 5 & $\begin{array}{c}\text { Daimler } \\
\text { Nissan } \\
\text { Renault }\end{array}$ & 22 & $\begin{array}{c}\text { Daimler } \\
\text { Mitsubishi } \\
\text { Nissan } \\
\text { Renault }\end{array}$ & 24 & $\begin{array}{c}\text { Daimler } \\
\text { Mitsubishi } \\
\text { Nissan } \\
\text { Renault }\end{array}$ & 21 \\
\hline Group 6 & BMW & 5 & BMW & 5 & BMW & 4 \\
\hline Group 7 & $\begin{array}{l}\text { FAW } \\
\text { Subaru } \\
\text { Suzuki } \\
\text { Toyota }\end{array}$ & 13 & $\begin{array}{l}\text { FAW } \\
\text { Subaru } \\
\text { Toyota }\end{array}$ & 6 & $\begin{array}{c}\text { FAW } \\
\text { Subaru } \\
\text { Toyota }\end{array}$ & 6 \\
\hline Group 8 & $\begin{array}{c}\text { Porsche } \\
\text { Volkswagen }\end{array}$ & 4 & $\begin{array}{c}\text { Suzuki } \\
\text { Volkswagen }\end{array}$ & 10 & $\begin{array}{c}\text { Suzuki } \\
\text { Volkswagen }\end{array}$ & 10 \\
\hline Group 9 & $\begin{array}{c}\text { Chrysler } \\
\text { Fiat }\end{array}$ & 10 & $\begin{array}{c}\text { Chrysler } \\
\text { Fiat }\end{array}$ & 8 & $\begin{array}{c}\text { Chrysler } \\
\text { Fiat }\end{array}$ & 6 \\
\hline Group 10 & Mitsubishi & 4 & - & - & - & - \\
\hline Group 11 & PSA & 10 & - & - & - & - \\
\hline
\end{tabular}

Table 4

\section{Manufacturers' bivariate correlations and significance tests}

\begin{tabular}{|c|c|c|c|c|c|c|c|c|}
\hline \multicolumn{3}{|c|}{2011 - 20 Cases } & \multicolumn{3}{|c|}{2012 - 19 Cases } & \multicolumn{3}{|c|}{2013 - 19 Cases } \\
\hline $\begin{array}{l}\text { Prod.// } \\
\text { Indegree }\end{array}$ & Value & $\begin{array}{c}\text { Significance } \\
\text { Test }\end{array}$ & $\begin{array}{l}\text { Prod.// } \\
\text { Indegree }\end{array}$ & Value & $\begin{array}{c}\text { Significance } \\
\text { Test }\end{array}$ & $\begin{array}{l}\text { Prod.// } \\
\text { Indegree }\end{array}$ & Value & $\begin{array}{c}\text { Significance } \\
\text { Test }\end{array}$ \\
\hline Pearson & .438 & .0516 & Pearson & .321 & .1842 & Pearson & .300 & .2100 \\
\hline Spearman & .602 & $.0047^{* *}$ & Spearman & .444 & .0583 & Spearman & .399 & .0917 \\
\hline $\begin{array}{l}\text { Profit// } \\
\text { Indegree }\end{array}$ & Value & $\begin{array}{c}\text { Significance } \\
\text { Test }\end{array}$ & $\begin{array}{l}\text { Profit// } \\
\text { Indegree }\end{array}$ & Value & $\begin{array}{c}\text { Significance } \\
\text { Test }\end{array}$ & $\begin{array}{l}\text { Profit// } \\
\text { Indegree }\end{array}$ & Value & $\begin{array}{c}\text { Significance } \\
\text { Test }\end{array}$ \\
\hline Pearson & .362 & .1156 & Pearson & .152 & .5480 & Pearson & .328 & .1693 \\
\hline Spearman & .482 & $.0315^{*}$ & Spearman & .183 & .4534 & Spearman & .177 & .4671 \\
\hline $\begin{array}{c}\text { Rev.// } \\
\text { Indegree }\end{array}$ & Value & $\begin{array}{c}\text { Significance } \\
\text { Test }\end{array}$ & $\begin{array}{c}\text { Rev.// } \\
\text { Indegree }\end{array}$ & Value & $\begin{array}{c}\text { Significance } \\
\text { Test }\end{array}$ & $\begin{array}{c}\text { Rev.// } \\
\text { Indegree }\end{array}$ & Value & $\begin{array}{c}\text { Significance } \\
\text { Test }\end{array}$ \\
\hline Pearson & .548 & $.0121^{*}$ & Pearson & .478 & $.0389^{*}$ & Pearson & .490 & $.0338^{*}$ \\
\hline Spearman & .603 & $.0046^{* *}$ & Spearman & .478 & $.0401^{*}$ & Spearman & .482 & $.0371^{*}$ \\
\hline
\end{tabular}

${ }^{\star} \mathrm{p}<.05^{* *} \mathrm{p}<.005$

the similarity between the amount of money an actor received and their revenue. It is suggested that the greater an actor's revenue is, the higher its money inflow is. In a similar fashion for Table 5, the results presented indicate that the greater a group's revenue is, the higher its money inflow is. The causality is not investigated here and it is not possible to affirm whether the revenue is higher due to the money inflow/greater centrality, or whether the inflow/ centrality is higher due to greater revenues. The value of $\alpha$ selected for both tests is $5 \%$, causing a maximum probability of $5 \%$ if the type 1 error is committed for 
Table 5

\section{Manufacturer groups' bivariate correlations and significance tests}

\begin{tabular}{|c|c|c|c|c|c|c|c|c|}
\hline \multicolumn{3}{|c|}{2011 - 11 Cases } & \multicolumn{3}{|c|}{2012 - 9 Cases } & \multicolumn{3}{|c|}{2013 - 9 Cases } \\
\hline $\begin{array}{l}\text { Prod.// } \\
\text { Indegree }\end{array}$ & Value & $\begin{array}{c}\text { Significance } \\
\text { Test }\end{array}$ & $\begin{array}{l}\text { Prod.// } \\
\text { Indegree }\end{array}$ & Value & $\begin{array}{c}\text { Significance } \\
\text { Test }\end{array}$ & $\begin{array}{l}\text { Prod.// } \\
\text { Indegree }\end{array}$ & Value & $\begin{array}{c}\text { Significance } \\
\text { Test }\end{array}$ \\
\hline Pearson & .537 & .0825 & Pearson & .614 & .0735 & Pearson & .599 & .0862 \\
\hline Spearman & .530 & .0973 & Spearman & .639 & .0718 & Spearman & .731 & $.0306^{*}$ \\
\hline $\begin{array}{l}\text { Profit// } \\
\text { Indegree }\end{array}$ & Value & $\begin{array}{c}\text { Significance } \\
\text { Test }\end{array}$ & $\begin{array}{l}\text { Profit// } \\
\text { Indegree }\end{array}$ & Value & $\begin{array}{c}\text { Significance } \\
\text { Test }\end{array}$ & $\begin{array}{l}\text { Profit// } \\
\text { Indegree }\end{array}$ & Value & $\begin{array}{c}\text { Significance } \\
\text { Test }\end{array}$ \\
\hline Pearson & .079 & .8205 & Pearson & .427 & .2237 & Pearson & .668 & .0554 \\
\hline Spearman & -.196 & .5620 & Spearman & .202 & .5940 & Spearman & .387 & .3073 \\
\hline $\begin{array}{c}\text { Rev.// } \\
\text { Indegree }\end{array}$ & Value & $\begin{array}{c}\text { Significance } \\
\text { Test }\end{array}$ & $\begin{array}{c}\text { Rev.// } \\
\text { Indegree }\end{array}$ & Value & $\begin{array}{c}\text { Significance } \\
\text { Test }\end{array}$ & $\begin{array}{c}\text { Rev.// } \\
\text { Indegree }\end{array}$ & Value & $\begin{array}{c}\text { Significance } \\
\text { Test }\end{array}$ \\
\hline Pearson & .694 & $.0124^{*}$ & Pearson & .873 & $.0009^{* * *}$ & Pearson & .894 & $.0009^{* * *}$ \\
\hline Spearman & .511 & .1116 & Spearman & .941 & $.0006^{* * *}$ & Spearman & .966 & $.0003^{* * * *}$ \\
\hline
\end{tabular}

${ }^{\star} \mathrm{p}<.05^{\star *} \mathrm{p}<.01{ }^{\star * *} \mathrm{p}<.001{ }^{\star * * *} \mathrm{p}<.0005$

each analysis, asserting a correlation between the observed data when, in reality, the variables are not correlated.

\section{Discussion}

Social network analysis (SNA) entails a way to understand multiple networks' relational and structural configurations (Borgatti et al., 2014). We explored whether a positive relationship is observable between multiple performance indicators and centrality metrics, focusing particularly on the relationships among centrality, groups, and organizational performance (Gulati \& Gargiulo, 1999; Provan et al., 2007; Wang et al., 2015; Zaheer et al., 2010).

Our results indicate that the actor's centrality in the network leads to higher revenue, which is aligned with the contingencies discussed by Wang et al. (2015). The automotive industry manufacturers benefited from better performance due to their larger size and their immersion in a more developed institutional environment, as explored by Wang et al.(2015). As our results point out, the network's central positions imply a gain in privileges (Hanneman \& Riddle, 2005), including direct access to resources and information, thus enabling greater revenues (Powell et al., 1999). As showcased by Zaheer et al. (2010), there exists an evident association between performance outcomes and network structure, combined with internal resources or organizational capabilities. This scenario can be observed by assessing many recent cases in the automobile industry, such as Renault-Nissan (https://www.economist. com/business/2010/06/10/ all-together-now, retrieved in 2020, June 29th), Ford-Mazda (Freyssenet, 2009), General Motors-PSA, Volkswagen-Suzuki, Renault-Nissan-Daimler
AG (Wang, Nguyen, \& Wang, 2016), Fiat-Chrysler (Ichijo \& Kohlbacher, 2008; Lee \& Jo, 2007), Nissan-Mitsubishi (https://www.economist.com/business/2016/05/12/ nissan-and-mitsubishi-make-an-alliance, retrieved in 2020, June 29th), and Fiat-Peugeot (https://www.reuters.com/ article/us-fca-m-a-psa/fiat-chrysler-peugeot-maker-psaamend-merger-terms-to-conserve-cash-idUSKBN2653AE, retrieved in 2020, June 29th).

Our results also point out that as some organizations and groups' centrality increases, this will be reflected in greater profits. There is a positive association between centrality and profits. However, it is not possible to generalize these results beyond this sample. New studies using multivariate analysis and the quadratic assignment procedure (QAP) regression (Borgatti et al., 2002) could be interesting to explore this causal relationship between centrality and profits.

The configuration of the relationship patterns in the networks allowed us to identify a strong community structure and to carry the analysis over to the subgroups' performance and their centrality, reinforcing the findings of previous studies in the automotive industry (Nohria \& Garcia-Pont, 1991; Ratajczak-Mrozek, 2017; Sacomano et al., 2016). In the first year there were a total of 12 subgroups and a total of 10 subgroups in the subsequent years, as also found by Garcia-Pont and Nohria (2002) and Sacomano et al. (2016). These subgroups identified the automotive industry's alliances, such as Nissan-Renault, Ford-Mazda, GM-PSA, and Fiat-Chrysler, for example (Freyssenet 2009). The community structure mentioned above assumes the characteristics pointed out by Tatarynowicz, Sytch, and Gulati (2016), given the 
observed partnerships concealed to operate strategically, generating higher revenues for the group and broadening one's influence on the rest of the members of the network (Nohria \& Garcia-Pont, 1991).

The strategic blocks formed by the alliances among a limited group of manufacturers enabled a joint strategy to achieve more significant revenues, mainly in 2013 (Nohria \& Garcia-Pont, 1991; Ratajczak-Mrozek, 2017). Furthermore, the results observed are consistent with the hypothesis raised by Koka and Prescott (2008), where in a scenario of stability, centrality is a better variable to explain differences in economic outcome for the organizations, since there were not any significant events between 2011 and 2013 that could modify the alliances and the whole network.

We ordered the data by year because our central database was divided yearly. Then, we included three main periods to examine the data more longitudinally. Over time, the networks underwent structural and relational changes. Our results indicate a strong community structure over time, which implies strategic blocks among the companies. These blocks change through new cross-shareholding, joint ventures, manufacturing contracts, and alliances. Our results also show that as some organizations and groups' centrality increased, this was reflected in greater profits over time. New SNA metrics would be interesting to capture the network dynamics over time, such as the stochastic actor-oriented models (Brandes, Indlekofer, \& Mader, 2012).

In addition, we highlight the flexibility with which alliances were classified in the guide. For instance, an alliance described in the guide as a "joint venture" was technically an alliance of technology or parts (https:// www.just-auto.com/news/proace-is-first-psa-built-toyotavan_id127942.aspx, retrieved on June 29th, 2020). These peculiarities confirm the existence of different governance structures in the automotive industry such as crossshareholding, joint ventures, manufacturing contracts, and alliances (Freyssenet, 2009; Matui \& Sacomano, 2017; Wang et al., 2016). This implies multiple forms of inter-firm cooperation and competition.

Regarding the measures of actors' and groups' centrality, it would be useful to analyze not only the main automakers but also all the actors belonging to the network, such as managers and suppliers. The collection of actors' attributes could be extended to a more substantial number of organizations so that the similarities between the correlations could be verified for a general network trend, not just for the manufacturers. We emphasize social network analysis as an interesting alternative to understand the relational and structural configuration of real networks (Borgatti et al., 2009).

\section{Final Remarks}

This work contributes to the theoretical aspect of evaluating the centrality of actors and subgroups and their specific performance. In it, it was possible to analyze the relationship between a centrality measure for actors and subgroups and their economic performance. Also, the use of the Louvain method made it possible to use the directionality and the weights of the relationships as preponderant factors in the delimitation of the communities.

The paper had several limitations that might be considered for future work. It could not determine one variable's influences over another, limiting itself to correlational measures. Also, taking into account the actors' and groups' centrality measures, it would be useful to analyze not only the main automakers selected by the Automotive News guide but also all other actors belonging to the network. Moreover, the collection of actors' attributes could be extended to a more substantial number of organizations so that the similarities between the correlations could be verified for a general network trend, and not only for the manufacturers. Furthermore, the restricted use of indegree centrality, at the expense of a broader measure, limits the understanding of an actor's centrality to the number of ties that "point" to that actor, represented here as the money inflow. Centrality provides rich inferences about the structural and relational positions of actors (Borgatti et al., 2002). As explored before, it implies prominent positions in the network, to access innovation, information, markets, and other competitive and institutional resources.

Most of the previous limitations could be remedied using more complex models and advanced statistical approaches. A multivariate analysis using control variables or a panel analysis would probably answer some of the questions remaining in our minds. Also, additional performance measures involving network distances, densities, and centralities could be considered for a more complete overview of our study object. We could not do that here due to time constraints, but we intend to do so in our future studies.

The discussion regarding organizational performance and centrality is vast and complex. The tested similarities 
among indegree centrality represented by the money inflow and three performance measures composed of production, profit, and revenue lead to a sole association between revenue and indegree centrality, evidencing the need for more in-depth and more complex analyses to further investigate or better explain the networks of alliances formed by automakers.

Regarding its empirical contribution, this research can help managers to understand the composition of the network of alliances in which a company finds itself. This composition makes it possible to evaluate the positioning, influence, and groupings of organizations, collaborating in strategic decision processes such as the selection of future partners or alliances, geared towards improving economic outputs.

\section{References}

AYNAUD, T., BLONDEL, V. D., GUILLAUME, J. L., \& LAMBIOTTE, R. (2013). Multilevel local optimization of modularity. New York: John Wiley and Sons.

BAMFORD, J. D., GOMES-CASSERES, B., \& ROBINSON, M. S. (2003). Mastering alliance strategy: $A$ comprehensive guide to design, management, and organization. New Jersey: John Wiley \& Sons.

BAMFORD, D. R., \& FORRESTER, P. L. (2003). Managing planned and emergent change within an operations management environment. International journal of operations \& production management, 23(5), 546-564

BARABÁSI, A. L. (2002). Linked. New York: Basic Books.

BELL, J. R. (2014). Subgroup centrality measures. Network Science, 2(2), 277-297.

BERRY, K. J., JOHNSTON, J. E., \& MIELKE Jr, P. W. (2014). A chronicle of permutation statistical methods. Cham: Springer.

BODIN, Ö., \& CRONA, B. I. (2009). The role of social networks in natural resource governance: What relational patterns make a difference? Global Environmental Change, 19(3), 366-374.

BORGATTI, S. P., EVERETT, M. G., \& FREEMAN, L. C. (2002). Ucinet for Windows: Software for social network analysis. Retrieved from https://pages.uoregon. edu/vburris/hc431/Ucinet_Guide.pdf

BORGATTI, S. P., MEHRA, A., BRASS, D. J., \& LABIANCA, G. (2009). Network analysis in the social sciences. Science, 323(5916), 892-895.

BORGATTI, S. P., EVERETT, M. G., \& JOHNSON, J. C. (2013). Analyzing social networks. New York: Sage.

BORGATTI, S. P., BRASS, D. J., \& HALGIN, D. S. (2014). Social network research: Confusions, criticisms, and controversies. In D. Brass. Contemporary perspectives on organizational social networks (pp. 1-29). Thousand Oaks, California: Emerald Group.

BRAILLY, J., FAVRE, G., CHATELLET, J., \& LAZEGA, E. (2016). Embeddedness as a multilevel problem: A case study in economic sociology. Social Networks, 44, 319-333.

BRANDES, U., INDLEKOFER, N., \& MADER, M. (2012). Visualization methods for longitudinal social networks and stochastic actor-oriented modeling. Social Networks, 34(3), 291-308.

BURT, R. S. (2009). Structural holes: The social structure of competition. Cambridge: Harvard University Press.

CONVERT, B. \& HEILBRON, J. (2007). Where did the new economic sociology come from? Theory and Society 36(1), 31-54.

DAS, T. K., and TENG, B.-S. (2003). Partner analysis and alliance performance. Scandinavian Journal of Management, 19(3), 279-308.

EVERETT, M. G., \& BORGATTI, S. P. (1999). The centrality of groups and classes. Journal of Mathematical Sociology, 23(3), 181-201.

FREEMAN, L. C. (1979). Centrality in social networks conceptual clarification. Social Networks, 1, 215-239

FREYSSENET, M. (2009). The second automobile revolution: trajectories of the world carmakers in the XXI century. London: Palgrave MacMillan.

GACH O., HAO J. K. (2014) Improving the Louvain algorithm for community detection with modularity maximization. In: P. Legrand, M. M. Corsini, J. K. Hao, 
N. Monmarché, E. Lutton, M. Schoenauer (eds), Artificial Evolution. EA 2013. Lecture Notes in Computer Science, (Vol 8752, pp. 145-156). Springer, Cham. https://doi. org/10.1007/978-3-319-11683-9_12

GARCIA, N., \& GARCIA-PONT, C. (1991). Global Strategic Linkages and Industry Structure. Strategic Management Journal, 12(1), 105-124.

GARCIA-PONT, C., \& NOHRIA, N. (2002). Local versus global mimetism: The dynamics of alliance formation in the automobile industry. Strategic Management Journal, 23(4), 307-321.

GOERZEN, A. (2007). Alliance networks and firm performance: The impact of repeated partnerships. Strategic Management Journal, 28(5), 487-509.

GOMES-CASSERES, B. (1994). Group Versus Group: How Alliance Networks Compete. Harvard Business Review, 72(4), 62-66.

GRANOVETTER, M. (1973). The Strength of Weak Ties. American Journal of Sociology, 78, 1360-1380.

GRANOVETTER, M. (2017). Society and economy. Massachusetts: Harvard University Press.

GRANOVETTER (2018). Economic action and social structure: The problem of embeddedness. In: Granovetter, M., \& Swedberg, R. The sociology of economic life (pp. 22-45). Oxfordshire: Routledge.

GULATI, R. (2007). Managing network resources: Alliances, affliations, and other relational assets. New York: Oxford University Press on Demand.

GULATI, R. (1999). Network location and learning: The influence of network resources and firm capabilities on alliance formation. Strategic management journal, 20(5), 397-420.

GULATI, R., \& GARGIULO, M. (1999). Where do interorganizational networks come from? American Journal of Sociology, 104(5), 1439-1493.

GULATI, R., WOHLGEZOGEN, F., \& ZHELYAZKOV, P. (2012). The two facets of collaboration: Cooperation and coordination in strategic alliances. The Academy of Management Annals, 6(1), 531-583.
HANNEMAN, R. A., \& RIDDLE, M. (2005). Introduction to social network methods. Califonia: University of California.

HANNEMAN, R. A., \& RIDDLE, M. (2011). Concepts and measures for basic network analysis. In J. Scott, \& P. Carrington. The SAGE handbook of social network analysis. London: Sage Publications.

HANSEN, D., SHNEIDERMAN, B. \& SMITH, M. A. (2010). Analyzing social media networks with NodeXL: Insights from a connected world. Burlington: Morgan Kaufmann.

HAUKE, J., \& KOSSOWSKI, T. (2011). Comparison of values of Pearson's and Spearman's correlation coefficients on the same sets of data. Quaestiones geographicae, 30(2), 87-93.

ICHIJO, K., \& KOHLBACHER, F. (2008). Tapping tacit local knowledge in emerging markets-the Toyota way. Knowledge Management Research \& Practice, 6(3), 173-186.

JACKSON, M. O. (2010). Social and Economic Networks. Princeton University Press.

KILDUFF, M., \& BRASS, D. J. (2010). Organizational social networks research: Core ideas and key debates. The Academy of Management Annals, 4(1), 317-357.

KIM, K. H., \& TSAI, W. (2012). Social comparison among competing firms. Strategic Management Journal, 33(2), 115-136.

KOKA, B. R., \& PRESCOTT, J. E. (2008). Designing alliance networks: The influence of network position, environmental change, and strategy on firm performance. Strategic management journal, 29(6), 639-661.

LEE, B.-H., \& JO, H.-J. (2007). The mutation of the Toyota production system: Adapting the TPS at Hyundai Motor Company. International Journal of Production Research, 45(16), 3665-3679.

LEWIS, J. M. (2011). The future of network governance research: Strength in diversity and synthesis. Public Administration, 89(4), 1221-1234.

MACAULAY, C. D., RICHARD, O. C., PENG, M. W., \& HASENHUTTL, M. (2018). Alliance network 
centrality, board composition, and corporate social performance. Journal of Business Ethics, 151(4), 997-1008.

MARIN, A., \& WELLMAN, B. (2011). Social network analysis: An introduction. In J. Schott, \& P. J. Carrington (Eds.). The SAGE handbook of social network analysis (Cap. 2, pp. 11-25) . London: Sage.

MATUI, P. C., \& SACOMANO, M. Neto. (2017). Relational governance of japanese automotive industry: Modularity and multiregional strategic action field. International Journal of Automotive Technology and Management, 17(4), 430-451.

MEHTA, C. R., \& PATEL, N. R. (2011). IBM SPSS exact tests. New York: IBM Corporation.

MOODY, J., \& WHITE, D. R. (2003). Structural cohesion and embeddedness: A hierarchical concept of social groups. American Sociological Review, 68(1), 103-127.

NEWMAN, M. (2006). Modularity and community structure in networks. PNAS, 103(23), 8577-8582.

NEWMAN, M. (2010). Networks. New York: Oxford University.

NOOY, W. (2003). Fields and networks: Correspondence analysis and social network analysis in the framework of field theory. Poetics, 31(5-6), 305-327.

ORMAN, G. K., LABATUT, V., \& CHERIFI, H. (2012). Comparative evaluation of community detection algorithms: A topological approach. Journal of Statistical Mechanics: Theory and Experiment, 2012(1), 1-20.

OWEN-SMITH, J., \& POWELL, W. W. (2008). Networks and institutions. In: Greenwood, R, The Sage handbook of organizational institutionalism, 596-623. Thousand Oaks, CA: SAGE Pubs.

PORAC, J. F., THOMAS, H., WILSON, F., PATON, D., \& KANFER, A. (1995). Rivalry and the industry model of Scottish knitwear producers. Administrative Science Quarterly, 40(2), 203-227.

POWELL, W. W., KOPUT, K. W., SMITH-DOERR, L., \& OWEN-SMITH, J. (1999). Network position and firm performance: Organizational returns to collaboration in the biotechnology industry. Research in the Sociology of Organizations, 16(1), 129-159.

PRELL, C. (2012). Social Network Analysis. London: SAGE Publications.

PROVAN, K. G., \& KENIS, P. (2008) Modes of network governance: Structure, management, and effectiveness. Journal of Public Administration Research and Theory, 18(2), 229-252

PROVAN, K. G., FISH, A., \& SYDOW, J. (2007). Interorganizational networks at the network level: A review of the empirical literature on whole networks. Journal of Management, 33(3), 479-516.

RATAJCZAK-MROZEK, M. (2017). Network Embeddedness. Palgrave Studies of Internationalization in Emerging Markets. New York: Palgrave Macmillan.

SACOMANO, M. Neto., MATUI, P. C., CANDIDO, S. E. A., \& AMARAL, R. M. d. (2016). Relational structure in the global automotive industry: Groups, networks and fields. Review of Business Management, 18(62), 505-524.

SACOMANO, M. Neto., \& PAULILLO, L.F.O. (2012). Governance structures in clusters: A comparative study in footwear and sugarcane's arrangements in the state of São Paulo. Revista de Administracao Publica, 46(4), 1131-1155.

SCHULZ M. (2016) Logic of Consequences and Logic of Appropriateness. In: Augier M., Teece D. (eds) The Palgrave Encyclopedia of Strategic Management. London: Macmillan.

SCOTT, J. (2017). Social Network Analysis (4th ed.). London: SAGE Publications.

SHIPILOV, A. V. (2009). Firm scope experience, historic multimarket contact with partners, centrality, and the relationship between structural holes and performance. Organization Science, 20(1), 85-106.

SODA, G. (2011). The management of firms' alliance network positioning: Implications for innovation. European Management Journal, 29(5), 377-388.

SMELSER, N. J., \& SWEDBERG, R. (2010). The handbook of economic sociology. New Jersey: Princeton university press. 
SMITH-DOERR, L., \& POWELL, W. W. (2005). Networks and economic life. In The handbook of economic sociology, 2(3), 379-402.

SOMEKH, B., \& LEWIN, C. (2005). Research methods in the social sciences. London: Sage.

SRIVASTAVA, M. K., \& GNYAWALI, D. R. (2011). When do relational resources matter? Leveraging portfolio technological resources for breakthrough innovation. Academy of Management Journal, 54(4), 797-810.

SWEDBERG, R., \& GRANOVETTER, M. S. (1992). The sociology of economic life. Westview press.

TATARYNOWICZ, A., SYTCH, M., \& GULATI, R. (2016). Environmental demands and the emergence of social structure: Technological dynamism and interorganizational network forms. Administrative Science Quarterly, 61(1), 52-86.

UZZI, B. (1997). Social structure and competition in interfirm networks: The paradox of embeddedness. Administrative Science Quarterly, 42(1), 35-67.

WANG, C.-N., NGUYEN, X.-T., \& WANG, Y.-H. (2016). Automobile industry strategic alliance partner selection: The application of a hybrid DEA and grey theory model. Sustainability, 8(2), 173.

WANG, H., ZHAO, J., LI, Y., \& LI, C. (2015). Network centrality, organizational innovation, and performance: A meta-analysis. Canadian Journal of Administrative Sciences, 32(3), 146-159.

WASSERMAN, S., \& FAUST, K. (1994). Social network analysis: Methods and applications. New York: Cambridge university press.

WESTPHAL, J. D., GULATI, R., \& SHORTELL, S. M. (1997). Customization or conformity? An institutional and network perspective on the content and consequences of TQM adoption. Administrative science quarterly, 42(2), 366-394.

WIT, B., \& MEYER, R. (2010). Strategy synthesis: Resolving strategy paradoxes to create competitive advantage. Australia: Cengage.

ZAHEER, A., GÖZÜBÜYÜK, R., \& MILANOV, H. (2010). It's the connections: The network perspective in interorganizational research. Academy of management perspectives, 24(1), 62-77.

\section{Financial support:}

CAPES - Coordenaçâo de Aperfeiçoamento de Pessoal de Nível Superior.

\section{Conflicts of interest:}

The authors have no conflict of interest to declare.

\section{Copyrights:}

RBGN owns the copyrights of this published content.

\section{Plagiarism analysis:}

RBGN performs plagiarism analysis on all its articles at the time of submission and after approval of the manuscript using the iThenticate tool.

\section{Authors:}

1. Augusto Squarsado Ferreira, M.Sc., Concordia University, Montreal, Canada. augustosferreira5@gmail.com

2. Mário Sacomano Neto, Post-Doctorate, Federal University of São Carlos, São Carlos, Brazil sacomanoneto@gmail.com

3. Silvio Eduardo Alvarez Candido, Post-Doctorate, Federal University of São Carlos, São Carlos, Brazil seacandido@ufscar.br

4. Gustavo Mendonça Ferratti, M.Sc., Federal University of São Carlos, São Carlos, Brazil.

gmferratti@gmail.com 


\section{Authors' Contributions:}

$\mathbf{1}^{\text {st }}$ author: Definition of research problem; Development of hypotheses or research questions (empirical studies); Definition of methodological procedures; Data Collection; Literature review; Statistical analysis; Analysis and interpretation of data; Critical revision of the manuscript; Manuscript writing.

$2^{\text {nd }}$ author: Definition of research problem; Development of hypotheses or research questions (empirical studies); Definition of methodological procedures; Literature review; Analysis and interpretation of data; Critical revision of the manuscript; Manuscript writing.

$3^{\text {rd }}$ author: Literature review; Critical revision of the manuscript; Manuscript writing. $4^{\text {th }}$ author: Literature review; Manuscript writing. 